Journal of Social Sciences (COES\&RJ-JSS)

ISSN (E): 2305-9249 ISSN (P): 2305-9494

Publisher: Centre of Excellence for Scientific \& Research Journalism, COES\&RJ LLC

Online Publication Date: $1^{\text {st }}$ July 2017

Online Issue: Volume 6, Number 3, July 2017

https://doi.org/10.25255/jss.2017.6.3.464.480

\title{
Analysis on symbolic meaning of drawing arts by elementary school children Sumanto
}

Elementary School Teacher Education, Faculty of Education, Universitas Negeri Malang

Jl. Semarang 5 Malang, East Java, Indonesia

\begin{abstract}
:
This research aims to analysis on diversity of symbolic meanings of drawing arts by elementary school children. The research subjects are the drawing works by elementary school students in East Java. The analysis uses qualitative descriptive analysis content and craftsmanship review. The research results are: (1) the symbolic meaning of child drawing relates to an illustration on an idea into visual element composition based on each child creativity style. (2) variety of symbolic meaning of children picture is Myself, Playing, Animals, Activity, Hobby, Landscape, Places, Public Objects, Arts, Performing art, Atmosphere, Environment, Events, Religiosity, Sports and Imaginative. The meaning of uniqueness of reality on children life is more dominated in the form of picture arts, based on the individual feeling sensitivity.
\end{abstract}

Keywords :

Symbolic Meaning, Child Picture, Elementary School

\section{Citation:}

Sumanto (2017); Analysis on symbolic meaning of drawing arts by elementary school children; Journal of Social Sciences (COES\&RJ-JSS), Vol.6, No.3, pp: 464-480; https://doi.org/10.25255/jss.2017.6.3.464.480. 
A picture as a work of visual art is made on a child' encouragement and desire on the reality of life he experiences, both structurally related to the art education he is studying; and through free expression of his willingness. There are many child's artistic activities, one of which is drawing, it is an example of behavioral work, which he sometimes creates it not to be separated whether it is an activity of playing or expression (Pamadhi, 2008). The condition of picture expression by elementary school children (SD) currently is a cultural visualization phenomenon having meanings as reality, and development in their environments. Each of the children's drawing works is a visual element with an interesting symbolic meaning to be understood as a universal language.

The encouragement and willingness for artistic expression as an artist can be caused by any problems and experiences of cultural traditions they believe in. Any things related to tradition are forms of representation and abstraction from the reality of elementary school children life. It can be stated that children's drawings are signs and markers of the dynamics of life found in a beautiful, happy, family-friendly system based on any beliefs or religions that it embraces. The encouragement for artistic expressionfound in children can also be influenced by development of global culture in everyday human life.

The existence of a child at the age of low grade according to (Tumurang, 2006, in Kustiawan 2012) shows the characteristics, among others are: (1) an obedient attitude to traditional game rules, (2) there is a tendency to praise himself, (3) prefer to compare himself with other children, and (4) there is a correlation between physical condition and school performance. While in the high-class age, they have the characteristics: (1) attention to practical concrete everyday life, (2) realistic, having curiosityand willingness to learn, (3) enjoy making peer group to play together, (4) complete tasks and activities freely and try to solve any problems by themselves.

According to Solehuddin. 2000 (in Masitoh, 2007) each child is different from one another, children have their own innate, interests, capabilities, and background of life. In further, it is express the basic natures of children, namely: (a) a child expresses his behavior in a relative spontaneous manner, (b) a child is active and energetic, (c) a child is egocentric, (d) a child has a strong curiosity and enthusiasm for many things, (e) a child is explorative and brave as the adventurer, (f) a child is rich in fantasy, lack of consideration in acting, short attention, fun of playing. However, at this age, children have shown the most potential learning period. It is also referred that at this time, it is as a period of school compatibility, which the attention and behavior of children's lives are filled with learning activities on various things, whether it is done at school, home, and environment surrounding the community where they lives; it is also performed with an expression of joy just like they are playing.

The current development of global culture, technology and information seems to provide effects on the imaginative ideas, themes, and symbolic meanings in the drawings made by elementary school children. Then, there isa phenomenon of picture diversity by elementary school children that is not bound and limited to the place where the child is. Although,a child lives in a remote village in a far distance with urban environment, but by the information and impressions presented on television, the children will quickly be able to access any new technological developments, information and new circumstances wherever it happens occur. This cultural phenomenon is certainly also believed to have an impact on the aesthetic understanding for elementary school children. This condition is 
certainly different from the life of elementary school children in the past. In the past, drawings made by elementary school children did not present any images showing the diversity of objects or new forms such as those we find out at the phenomenon of current image creation. Examples of elementary school picture phenomenon are presented in the drawings of television, hand phone, parabola, computer, telecommunication tower, wheel toys, game toys, flyover, multi-level buildings, MOL, toll road, hot air balloon, flyover, formula car, imaginative figures, Batman, Superman, Barby dolls, and other actual events existing in their environment.

Based on the history of human life and its relics, it is found the existence of symbols related to the existing culture at that time. The symbols are interpreted as identity, markers, characteristic of human community found in a place or region. The symbols created are in the forms of drawings, writings, cultural artefacts (objects), music, songs, signs, cues and others. Similarly, life of elementary school children with all of their activities and abilities also continue to grow in line with the development and progress of their culture. Children in art activities, especially drawing, also have the ability to create or present identity, in the form of visual symbols based on their drawing idea / creation that they create. In this regards, it can be found that there are symbolic meanings in the children's drawings.

Creation of various kinds of visual artworks can be understood as symbolic, or for symbolization according to any ideas, or anythingto be expressed according to its creators. Artwork drawings are created by using visual elements according to the creations intended by their creators. The visual elements include dots, lines, shapes / forms, colors, textures (impression materials), contents, space and light. Art is the activity and the result of human beauty expression through media of line, color, texture, field, volume and space (Salam. 2001).

Through the use of visual elements, a form of drawing art can express symbolic meanings either related to reality (life), one's experience, natural events, emotional social conditions and developed knowledge. The diversity of visual artworks includes artworks by elementary school children or at the age. All types of visual artworks certainly cannot be separated with certain symbolic meanings.

The symbolic meanings are based on the understanding on the function / purpose of its creation. Works of art are categorized into fine art and applied art. The fine art is a type of art which in its process of creation, it provides more emphasis on the expression of ideas, aesthetic-artistic value feelings and is not intended as a practical functional item. For examplesare paintings, sculptures and others. The applied art is a type of art which in its process of creation, it provides more consideration on the value of function / practical use and the beauty of its shape. Nevertheless, if it is seen from the presentation of works of arts, it still expresses beautiful shapes. The examples of visual art works are handicraft objects, building arts.

Likewise, understanding the symbolic meanings, these can be categorized based on the forms of visual artwork into three groups: (1) Two dimensional visual art (dwimatra) with the characteristics of flat impression and only providing one-direction of beauty. The examples are pictures, paintings and prints. (2) Three dimensional visual art (trimatra), has the characteristics ofwhole (overall $=$ wungkul) impression and can give the 
impression of beauty from several directions. The examples are art sculpture, building art, some handicrafts, decoration and other arts. (3) Two and three dimensional visual arts (dwitri-matra), has characteristics to show the impression of beauty in a flat and full impression. For example is high relief also called as embossed images.

Based on the above description, it is confirmed that the children drawing seen from its form is a two-dimensional visual artwork having certain beauty and uniqueness symbolic meanings. To understand the symbolic meaning values in the children's drawings, among others can be based on the benchmark of an assessment, either absolutism, anarchy, or relativism. The symbolic meaning of absolutism is the agreement reached through the deliberations or conventions that have been made and applied in the community of a society as long as there is no change. The symbolic meaning of anarchy is a subjective judgment by a person according to his will by looking at the agreed limitations. While the symbolic meaning of relativism is an assessment using not absolute aesthetic criteria or in other words according to the individual sense of assessment. There is subjectivity according to person taste to interpret the symbols found in visual artwork.

It can be meant that the symbolic nature of visual artwork is an act of human that can make something more useful for itself, the surroundings consisting elements of beauty, atrractive, according to the agreed value standard. In this context, the existence of children's drawing is believed to be the object of study to be appreciated and understood as a unique, creative, expressive symbolic meaning as a form of children visual artwork.

It is interesting to study and review the subject matter of children's drawing certainly in a more comprehensive manner related to how the phenomenon of visual elements and symbolic meanings of children's drawings in the present era. Based on a research: " $A$ Study of Aesthetics and Typology of Elementary School Children Drawings in East Java" (Sumanto, et al., 2011) the results are as follows. (1) children's drawing is a form of creative ideas representation, uniqueness, individual expression, children expression on their experiences, reality, and imaginative power. Each drawing has a specific, interesting, dynamic, straightforward visual element, and there will be no any the same impression between one drawing and another. Children's drawing relates to themselves, nature, surrounding environment, culture, art, animal world, experiences, activities, natural events, objects as public places, imaginative, and others. (2) Every child basically faces a development period of visual expression according to their innate abilities (talents), although there is a variation on their talents. The development period of each children's drawing seems to not always go hand in hand with or at the same time as their ages. There are children having ability to draw faster than their periodization age, and vice versa there are also slow ones. (3) in general, there are more portion of typology, style, and impression of children's drawing space in the type of Visual, and just small portion in nonvisual (Haptic) type. (4) The impression of children's drawing space is seen in the physical structure of visual elementshowing diversity of space impression creations: laying down, stacking, cover-closing, bird perspective, and downsizing.

The result of the research titled "Study of Characteristic of Expression Picture of State Elementary School Karangbesuki 4 Malang Students" concludes that: there is $39 \%$ of students' drawings having theme of nature, there is also students' tendency to use colored pencil and crayon to color with dash-based hatching technique. There is $58 \%$ of drawing having stereotype objects and there is $51 \%$ having buildup in the creation of its impression 
space. This shows that: (1) the expression of elementary school students' drawing characteristic is mostly having the theme of nature with the objects such as plants, animals, mountains, sea, (2) in general, the students' expression drawing is in type of visual, small parts is haptic and mixed images, (3) most of periodization drawing is chart, and some others face faster period of drawing than his age (Maghfiroh, 2012).

From the above research findings according to the author, there is a phenomenon of uniqueness on the children's drawing visualization that can be analyzed from the study of visual elements and symbolic meaning of the children's drawings. The study of art is focused on describing the diversity of visual elements found in every children drawing work. The study of the drawing symbolic meanings is intended to describe the tendency of the meanings, signs, cultural symbols that is presented, and is individual. Each shape of children's drawing has a certain unique symbolic meaning value that is presented. In this case, the children's drawing is an expression of message, ideas and emotions by using visual symbols according to each child's style characteristics.

Based on the problems presented above, the author believes that it is very urgent to conduct the study of visual elements and the symbolic meaning of children's drawing. In addition that the object research has attractiveness and importance to study, there is also not any fundamental research. Therefore, the research on the elementary school children drawings in East Java has considerations: (a) the elementary school children's drawing in East Java is a form of the diversity of social-cultural and geographical life characteristics in East Java, Madura and other etnic in East Java, (b) the descriptive information on the visual elements and symbolic meaning of the children's drawing is one of the important assets of knowledge and culture to be studied and preserved, (c) as the author knows, recently, there is no research results on visual elements and symbolic meaning of children's drawing that can be utilized in the art education in Elementary School level.

The study of visual elements and symbolic meanings of children's drawings is part of a study on "Theme Review and Children's Drawing Objects" published in the Journal of Elementary Schools (Sumanto, 2014) with the following results. First, diversity on children's drawing themes relates to the illustration of an idea into an image according to the children's creative style. The diversity of children's drawing themes is the themes of Myself, Playing, Animals, Activity / Hobby, Landscape, Public Places or Objects, Arts, Performing Arts, Atmosphere, Place / Environment, Events, Religious, Sports, Imaginative, and Poster. Out of these various themes, there is a similarity of titles presented on each drawing, and there are also differences. The themes are related to the objects of people, animals, plants, imaginative objects having so many characteristics of style or manners to describe them. The theme of children's drawings is a manifestation of life's illustration and expresses natural surroundings, human behavior, animals, and cultural products and activities according to the children's emotional power.

Second, the diversity of "Objects or Shapes" presented in the children's drawings is generally in the objects of human, animal, plants, cultural objects, and other imaginative creations. Each of the children's drawings can be recognized as having the same object display, and there are also similar objects, and there are also different objects. The elementary school children mostly often or tend to make drawings of natural landscape, these can be identified the diversity of displayed drawing objects. 
This research on the visual element and symbolic meaning of elementary school children's drawing is intended in general to describe the diversity of elements and the symbolic meaning in elementary school children's drawings in East Java. The specific purposes are to describe: (1) the diversity of visual elements (lines, shapes, colors) of the children's drawings, (2) the diversity of symbolic meaning found in the drawing implied in the title of elementary school children's drawings in East Java.

\section{Methods}

The design used is descriptive qualitative. The qualitative research is always descriptive, meaning that the research results are analyzed in the form of detailed description on a phenomenon. This approach is chosen because it is in accordance with the characteristics of qualitative research (Miles and Huberman 1992, Sutopo 1990, Rokhmat, 2004), which is very suitable and provides an opportunity to provide qualitative understanding and explanation on a phenomenon in a depth and holistic manner.

In examining the visual elements and symbolic meanings of children's drawings, it is based on the approach of artistry, and characteristics of children's drawing visualization based on both physical structure and esthetic structure. According to Sachari (2004) by the aesthetic approach through art criticism, an object of art can be observed from symbolic meaning, social meaning, cultural meaning, beauty meaning, economic meaning, or religious meaning. In this case, each art object will present the dimensions of dynamics, style, technique, aesthetic ideology, lifestyle influences, relationships with behavior and environment. Based on the research design, the source of research data is obtained from documentation on the elementary school children's drawing in East Java. In this case, the researcher acts as an instrument serving a role as observing and collecting data in depth.

The research subjects are documents of elementary school children's drawings from 24 Cities / Regencies in East Java in the period of 2011-2013. The research subjects were collected by collecting documentation on the children's drawings from the sample areas of Surabaya and Malang city, Blitar city, Malang regency, and Jombang, and the small cities such as Bangkalan, Trenggalek and Lumajang districts and others. The instrument used is the identity observation instrument used to collect data related to: the origin of the children's drawing, name, age, sex, size of drawing, and year of production. Instruments of guidelines for documentation are used to collect data related to: (a) visual elements namely: lines, colors, and other elements, (c) the drawing media / tools used and art techniques; and (c) the symbolic meanings.

The data and information collected were analyzed by using qualitative descriptive qualitative analysis and artistic analysis analysis. The analysis steps were taken through the processes of reduction, presentation and verification of data (Miles and Huberman 1992, Sutopo 1990 in Rokhmat, 2004). The data analysis was conducted through the method of analysis of art with stages: (1) Data review and reduction. The data reduction is intended as a step or process of eliminating or removing any unnecessary data, simplifying, focusing, sorting or selecting and sharpening the data obtained. Sumandyo (2006) stated that the data reduction is supposed to simplify, abstract and transform rough data from some field notes since the beginning of data collection. (2) the data presentation is intended as an analytical process to compile any data findings in the form of tables and descriptive expositions from general to specific subject and to provide meaningful data. 
The descriptive analysis of children's drawing research focused on the diversity of symbolic meanings of elementary school children's drawing.

\section{Results and Discussion}

Out of hundreds of elementary school children's drawing studied, it is conducted the identification on symbolic meaning found in the children's drawings that meets the predefined indicator requirements. In this case, actually on each elementary school children drawing, it has a unique symbolic meaning and will not have the same impression between one image and another image. Although there is the same size of drawing but, in the visual elements, it can be seen different lines, shapes, colors, appearances / compositions. The display of an elementary school children drawing is as a representation of creative ideas, uniqueness, individualistic expression, or self-expression of the children experiences, reality, or beautiful imaginative world having cultural and other meanings from the simplest one to the most elegant form elementary school children's drawing, namely having detailed precision.

The results of identification on the symbolic meaning of children's drawings related to the beauty of elementary school children's drawingthat are also understood as cultural meanings are as follows: (1) the symbolic meaning of themselves, the meaning of the child with the school, himself with the teacher, (2) the symbols of experiences for example playing, having picnic, gardening, celebrating birthday, and others, (3) the art symbols of jaranan(horse) dance, shadow puppets, carnivals and others, (4) any symbols relating to information that is heard, viewed, or read through printed media such as events of Tsunami, Earthquake, flood, rainbow, landslide and others, (5) religious symbols such as Idul Fitri, worship at church, worship at mosque and others. Here is the results of symbolic meaning of children's drawings. The meaning of elementary school children's drawing shapes (Sumanto 2013) can be implied from the themes of drawings, the title of drawing, the object of drawing, the color of drawing or anything else that is expressed as visual language.

\section{Symbolic Meaning of Myself}

There is a variation on the symbolic meaning of myself in the children's drawing work. The symbolic meaning of myself is expressed in the form of any drawings related to the children favorite objects, going to school, school friends, friends, dancing together, hanging out with friends and others. My self means as the child's self symbol. The existence of each child must be related to the personal or small human figures who are in physical and psychological development. The children are also not separated with the ability of intelligence, skills, fun, activities done, goods / objects that they have, desire, imagination, and other selfness. The condition of creativity drawing on a child can reflect the existence of symbolic meanings such as the meaning of my activities (the activities done by the child), the meaning of objects it possesses (for example My house), and also the meanings related to something that they like (My preferences) and the ideals. (My ideals and preferences).

The diversity of the child's self-expression is the drawings of his face, one's face, such as his father, mother, brother, idolized figure, himself and his pleasure, also self meaning and illustration of ideals, and the environment in which he lives. The child's self-meaning is a form of his selfness, which is around him, at home, at school, on the playground and other children's world activities being himself. The drawing work expresses the existence of 
child in the form of "my self" as a reflection of selfexistence. The following isthe drawing work with meaning of my self.

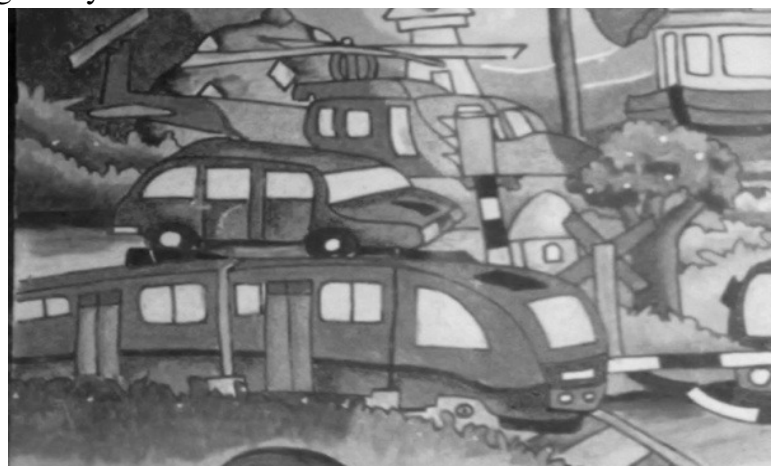

Work by: Bagus Pamungkas (10 years old), SD Ampeldento 2 Malang. Title: My Favourite Vehicle

The means of transportation taken as my favorite object in this drawing is in the form of Railway, Sedan Car, Helicopter, and Ship. This shows various means of transportation as the favorite of elementary school children. The impression of space in the drawing is stacking, where there is an impression of space with the characteristics of object is drawn closely at the bottom of the drawing area, while the objects located farther away are put at the top of the drawing area. This is shown by the railway object pictured below the drawing plane, the car is drawn above it, and in the drawing, there is a train object beneath the image of plane colored in orange, pink and blue. The object of car is colored with orange and pink. The Helicopter object is colored in light blue with dark blue gradations. While the overall color of glass on the entire transportations is colored with white. There are also plants colored in light green with dark green gradations. While behind the drawing of the helicopter, there is a picture of gray building. The stacking is intended to make the helicopter drawing farther from car and train drawing. There is orange sky coloring made by the children with gradations of yellow, it is intended to present the sky looks at the afternoon. While the road on the drawing is colored in gray.

There are any interesting or memorable experiences for the children such as activities done like bathing with friends on the river, taking trains, dancing with friends, hanging out with friends and others. Likewise, there is a child's selfness to declare his possession through the drawing visualization. Expressed by (Pamadhi, 2008) that one of the children's drawing styles is a portrait style namely the image of a person's face, such as a father, a mother, an elder, an idolized figure, including a portrait of himself; also an example of a good friend, My House, My Private Room, My Classroom, My Teacher in the classroom, My Classroom, Birthday and more.

\section{Symbolic Meaning of Playing}

Playing for elementary school children has become a part of everyday life having no deadlines, places, different types of playing either done alone or with friends at house, school and elsewhere. The meaning of playing for children is also related to the meaning of time. To get a fun atmosphere or fun in paying for children and their experiences, it should be done in one place at certain moment. For example playing on the beach, playing at night, playing in solitude to remove silence (Sumanto.2013) 
The playing activities and experiences is expressed in the form of various drawing such as the following works.

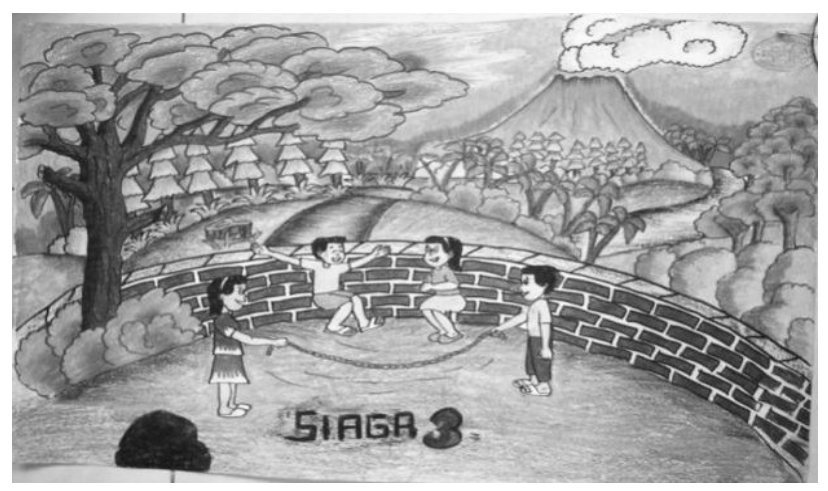

Work by: Indah Cahyandini (12 years old), SDN 4 Penganjuran Banyuwangi. Title: Playing Jump Rope.

The prominent element found in the drawing of four children playing a jump rope above is a beautiful place with a low walled brick wall environment behind it. There are also trees, flowers and mountains with the morning atmospherebecause there is a yellow impression in some trees. The theme taken by this work is environment. Because it describes the atmosphere of mountains and activity by a number of children in yellow, green and red colors. The tool used by the childto draw is crayons. Periodization of realism in her village presents beautiful and peaceful atmosphere behind the walls of 4 children who are playing jump rope. Indah drawing does not imitate other drawing or subject, she draws with nonvisual style. The impression of space in the drawing is the perspective of birds because it is seen the walls that are drawn curved and behind the wall, it can be seen trees drawn in diverse manner. The composition of drawing is balanced between the right and left sides as it is balanced by the trees on the left and the mountain on the right.

The uniqueness of drawing is to have fine lines like bricks on the wall that are looked neat, the trees are lined up so it is pleasing the eyes. The color gradations have also been seen starting from the trees, the soil, the mountains, the sun. In addition, there is the wriiten "Standby 3" meaning that the mountain behind them has a status of standby 3 . This drawing tells that although in a vigilance condition, the children still play to avoid any restless mind towards the standby status of the mountain. I interviewed Indah during break time, Indah said that she liked to draw scenery, she liked yellow color.

Regarding the symbolic meaning of "Playing" which is the source of ideas in the children's drawings, it shows a correlation between the life developments of children who are playing. In general, there is an activity of playing performed by the children namely playing Jump Rope, Yoyo, Ball, Marbles, Kites and others. Likewise, the children want to express the experiences of playing by showing with whom the children play and where the children play. This is confirmed by the drawing titles as follows: Playing with Sister, Father, Neighbor. Playing in Gardens, Rivers, Neighbors, and Parks. 


\section{Symbolic Meaning of Activity}

The symbolic meaning of activity on children's drawing has quite diverse presentations and is interesting to appreciate. There are activities performed by the children themselves, the activities performedwith others (friends, brother, sister, family and others). Likewise, the symbolic meaning of the activity and the sport is a representation of children's lives about various activities (hobbies) attracting attention to be expressed into drawings.

The children's sensitivity and intelligence are shown in their ability to interpret an activity and also good hobby done by the children, or done by people in their environment. In this context, there is a variety of activities in human life whether daily work activities, or activities leading as a pleasure or hobby, both are also a concern in the thoughts and feelings of elementary school children. This can be seen from parts of the diversity of children's drawings that clearly and specifically express the symbolic meaning of various activities (hobbies). There is a symbolic meaning of routine activities performed by a person, by children every day. For example for children, the routine activities are going to school, studying, reciting, praying (worship) and others. There are also activities performedby a person as a profession or livelihood according to the types of work. The following are examples of drawings illustratingthe symbolic meaning of activities (hobbies) that attract the attention of elementary school children.

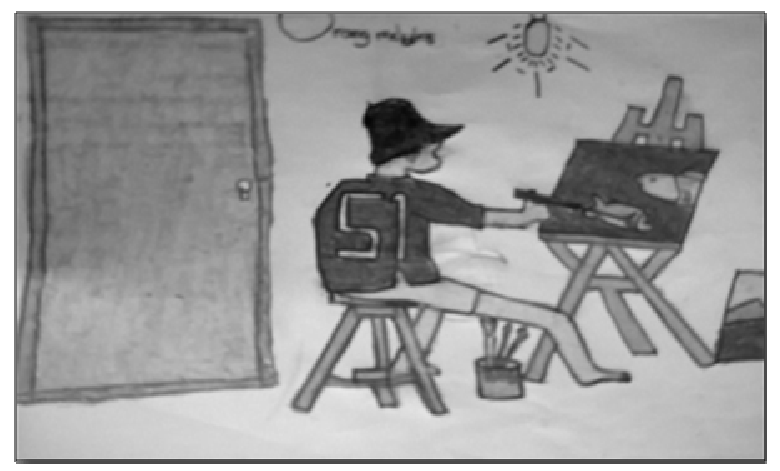

Works by: Anshori (8 years old), SDN Umbul Blitar, Judul: Painting

The elements of line, shape, shape, waking, color, texture, lighting elements of the drawing are classified in a pseudo-naturalist period as they represent more concrete and natural drawing of objects such as the original. This period is also shown by the calculation of quality of three dimensions (perspective space) and lighting on the drawing. The activities performedby children with family, friends, and activities performed by human beings around the child's life are parts of expression that can be found in the children's drawings. Titles of the drawing are with the theme of "Activity", namely People Painting, Family Work, Family Activity, Planting Flowers, Adventure, Persami, In Zoo, Mountain Journey, Shepherd, Hilda is Writing, Going to Night Market, Going to Museum, in the classroom.

\section{Symbolic Meaning of Sports}

Sports for children is like a playing activity that every time they will do. Children's interest in sports activities also influences on the ideas / ideas in the activity of drawing, 
painting. Based on the documentation of children's drawings expressing the sports, the symbolic meaning is as follows.

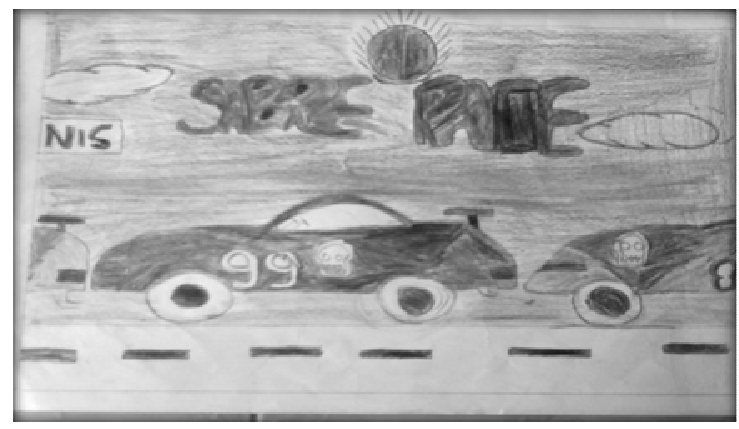

Work by: Risky Dwi (11 years old), SDN Kolomayan 02 Blitar. Title: Car Race

There are symbolic meaningspresented in the drawing above, among others, the meaning of elements of lines, fields, shapes, and colors. The line element includes almost all aspects in the drawing, such as cars, roads, and clouds, all of which originally come from the line element. The element of field is in the street image (below). The element of shape is in the drawing of car and cloud, these have begun to form like it has a space inside. The element of color is also presented in the drawing almost entirely from the drawing above. There are various colors in the drawing above, for example between the car (front) and the car behind it, it shows that these objects are different things. Light is not visible in the drawing above, it is seen from the absence of light dark colors in the drawing.

The car is colored red-black, purple-green as a reality in the toy car. In addition, the periodization of realism is also found in the cloud drawing given bluish-white color, such as its reality. The typology drawing is visual. Children draw on what they see. The color and shape are the same as what they see in toy cars. The space impression is on the drawing perspective of bird. The impression is in the drawing of the drawn street as seen from above.

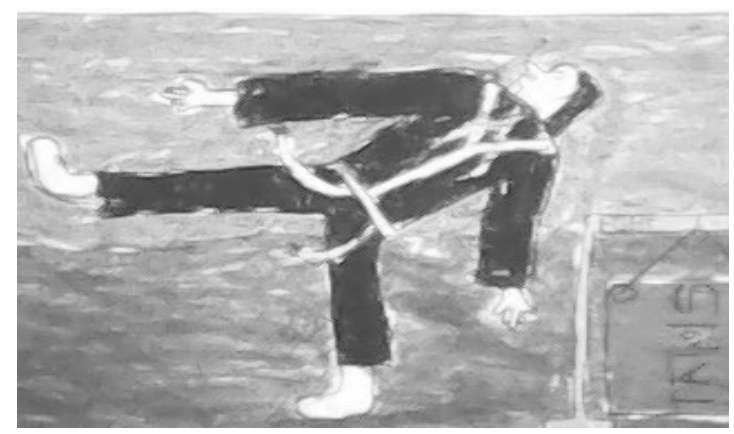

Work by: Adi Santoso (11 years old), SDN Kademangan 2 Blitar, Title: Martial Arts

In the drawing above, there is a symbolic meaning related to the object of a man exercising Pencak silat (Martial art). There is a sense of motion, meaning of clothing showing the characteristic of a fighter and the white belt he wears. The art elements 
presented in the drawing above, among others are, elements of line, fields, shapes, and colors. The element of line is presented in almost all of the drawing parts, including the people. The element of field is shown in the drawing by geometric field (seen in the drawing of the person) as well as the ageometric field (seen in the figure of the person, the shape element in the drawing above forms the human.) The element of color used is in a quite small portion. It can be seen from the absence of a dark impression of light on the drawing.

\section{Symbolic Meaning of Place}

The symbolic meaning of a place in the children's drawing work is quite varied. There are drawing expressing the symbol of place as the meaning of urban, crossroads, sidewalks, factories, neighborhood houses, city parks, playgrounds, supermarkets and others. The symbolic meaning of a place can be confirmed its existence through its form, its name, condition of the place, or its function. Similarly, there is a symbolic meaning related to the beauty of natural scenery, such as beaches, mountain waterfalls, city parks, and others.

The intended place is a location, territory, area, object as the children's concern to be expressedby symbolic meanings according to their impression in the place. The symbolic meaning of the place can certainly be related to natural environment, surrounding natural scenery having certain beauty, and also any public places as placesto attract people so that they can see and enjoy, these are interested by elementary school children. There are certain places having ability to attract children to be exposed to their drawings. The following are examples of symbolic meanings of the children's drawings having tendency to have a theme of public places or objects.

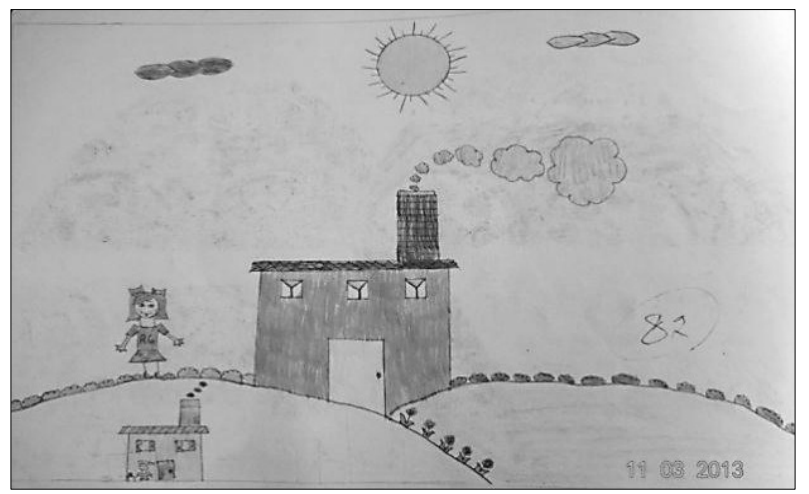

Works: Suci Cantika (10 years old), SDN Kalangbret Tulungagung. Title: Factory

In the drawing, it is expressed the symbolic meaning of the existence of a girl standing beside a factory. It is seen also something like a hill or a mountain or land, there is also a flower laying in the tilt drawing. The drawing tends to be haptic, the style of drawing is dominated by the child's imagination. What she has seen is expressed according to her creative power freely as it is seen from the drawing of shape of a factory building, smoke above the factory, this show that the child's drawing is factory. The color applied to the drawing is pretty good, it does not give full color for the drawing so that it looks pale and less attractive for viewers. Arrangement of objects such as factories, girls, flowers is less in accordance with reality, the concept of spatial arrangement found in the child's drawing 
is created with imagination. Flowers under the plant are illustrated with the concept of laying down.

The existence of a place / object presents a new knowledge symbolic meaning and an experience of interest and not easily forgotten one. There are quite many of children's drawing expressing the symbolic meaning of public places or objectsalong with the atmosphere describing its situation. It can be found the atmosphere meaning of a place, office, city street, factory, daytime city crowd, neighborhood, city park, playground, supermarket owned by Ayunda, Blitar Station, School Canteen, pollution factory in the City, beautiful Balekambang Beach, Safari Park, Post Office. Clean environment, dusky garden, great views in the morning, beach in the afternoon, lake, mountains in the morning, Trains in the afternoon, comfortable bedrooms, living room, study room.

\section{Symbolic Meaning of Natural Landscape}

The nature, the environment or the natural landscape around the children are as sources of ideas mostly expressed into the drawings. There are very diverse ways to describe nature, natural landscape, good scenery in the mountains, beaches, cities, surrounding houses, forests, rivers and more. various children's drawings can provide symbolic meanings of natural landscape objects, and beautiful surrounding nature. The following is as an example of symbolic meaning expression of natural landscape.

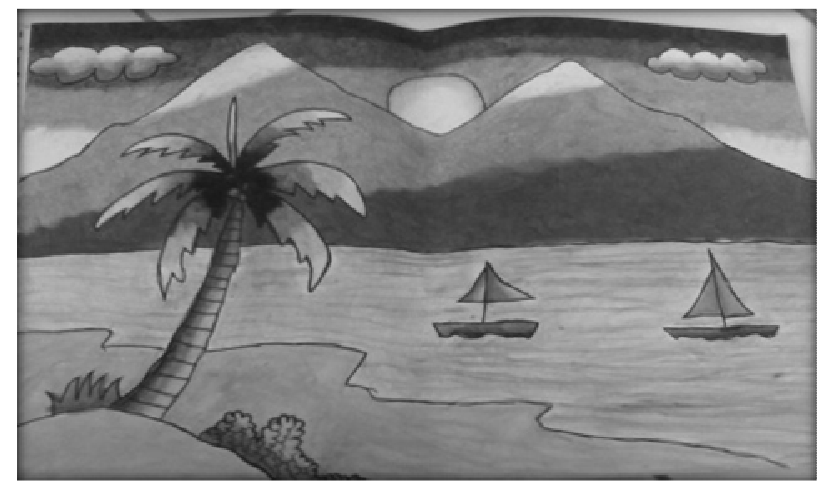

Work by: Puspita Utami (10 years old), SDN Sumbersari Blitar, Title: Landscape

There are symbolic meanings presented by the visual elements in the drawing above namely the elements of line and shape including the drawings of mountains, trees, sun, boats, sea, shrubs, beaches and clouds. The element of color is filled all the drawing, it has the orange-colored sun because it illustrates afternoon atmosphere, the leaves are green and yellow and the stems are light brown, the sand is light brown, the sea is blue, the boat is light brown and the screen is colored, all of which are given different colors because they also provide different meanings from one to another. To add to the beauty of the drawing, it can already see the gradation and color combination.

The period of development of child's drawing is realism. The child is able to draw and color in accordance with the reality. The typology found in the picture above is visual. Impression of space presented in the drawing above is the impression of reduction and stacking. The diminution impression is on the shrinking drawing of ocean getting to the 
end. The stacking impression is on the drawing of boat which the drawing remains the same even though one boat is far ahead another, the boat ahead should be drawn smaller.

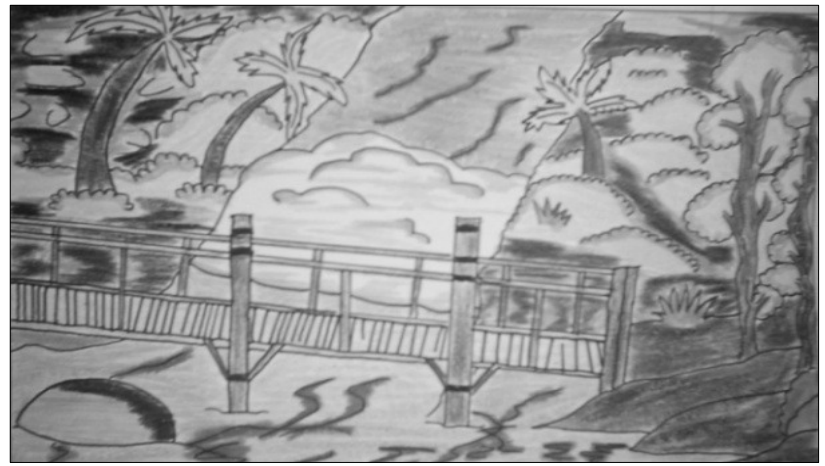

Work by: Faradina Wahyu (13 years old). SD Mangliawan Malang. Title: Fountains

The symbolic meaning of Faradina's drawing is the objects of waterfalls, trees, grass, shrubs, rocks, bridges, water, earth, compositing the impression of uniting appropriately. The impression of drawing space still tends to the bird's perspective. There are the drawing objects as if those are seen from above. There is a unity between one object and another, such as a waterfall is located in a dense forest, there are bridges and rivers in the waterfall flow as the center of attention on the drawing.

There is an emerging perspective, but based on its own eyesight and it has not shown any actual comparison. Typology of waterfall landscape drawing is more visual-realistic. Although the child's drawing pays less attention to the proportion or making diminution on farther objects, but the child is already using appropriate colors to the actual objects. The color of chocolate at trees, blue at water, green at leaves, brown at soil, and black at stone indicate student's accuracy in describing the actual situation. The shape of object in the drawing is expressed appropriately, so that it creates feelings of pleasure and melancholy. The drawings are expressed with egocentric sensations such as forests, environments, waterfalls, and others. The characteristics of the child's drawings are dynamic, meaning that the drawing adjusts to the actual shape such as the drawing of trees, bridges, water, soil, rock, although the waterfall drawing is less perspective.

The symbolic meaning of natural landscape for children is one of the most expressed source of ideas and objects in the drawing works that they make. This "Landscape" symbol is a variety of nature, surrounding environment is expressed into the composition of drawing according to the creation of each child. The meaning of landscape is related to waterfalls, forests, beaches, beautiful mountains, landscape in the neighborhood, beautiful garden scenery, villages, landscapes in the forests, rural scenes, and more. The natural surroundings for the world of child expression are also objects of meaningful beauty. In fact, almost every child draws freely, for example, the meaning of the shown object is nature / natural environment. They do not forget to express the objects such as mountains, soil, trees and others. The freedom of the child in expressing the natural surroundings is the desired form of behavior, fair and natural (adaptive behavior). This suggests that creative or aesthetic development has started to be influenced by realistical thinking (Syafii 2002). 
Symbolic Meaning of Animals, Arts, Religiousity

The symbolic meaning of a drawing workof "Animals" expresses various types of animals shown in an elementary school child's drawing. The child's interest in expressing an animal's object is not limited by its age factor. There are quite a variety of symbolic meanings such as terrestrial animals, surrounding waters, pets, loved pets, and wild animals can be described by children. The ability has carefulness ability in understanding the existence of animals, this can seen in the drawing objects and titlesnamely the Geese in my environment, my Cow is Playing, Snail, Sheep and Zebra, Turtles, Wild animals, Horse, Farms, Hungry Rabbits, Animals protected. Zoo, Safari Park, Animal Husbandry, Cats, Birds, Elephants, Chickens, Goats, Butterflies, Centipede, Animals living in the waters (Fish, Squid), and others.

The symbolic meaning of "Art" in the children's drawing is a form of local wisdom expression from the cultural diversity in a region. For children, the existence of art formssuch as dances, puppets, reog and other arts can be a source of interesting ideas to be expressed in drawing works. In this case,child's art works according to (Jazuli, 2008) are as a symbol system always related to a unique cultural context. Similarly, there are children's drawings in East Java with the theme of arts expressed in a variety of art symbols, such as performance art of wayang orang, dancers, Jaranan-Horse dance, dance, dance Banyuwangi dance, wayang Hanoman, Wayang Kulitperformance, guitar playing, jaranan-horse, Reog Mini From Ponorogo, Drumband Parade, Madura Batik Handicraft with Tasikmalaya Style, Saron, Knowing Indonesia Culture, and others.

The symbolic meaning of "Religiosity" expresses the beliefs as an experience of religious ritual based on the behavior of religious teachings that the children embrace. The forms of religious symbols in the children's drawings are religious expression based on the feelings, beliefs, happiness, and gratitude found in the children. Some Moslem (Muslims) children provide meanings of religious activities that they believe in the symbols of Moslem Clothing, going out to the mosque, hitting Bedug, ask apologize on the feast of Idhul Fitri. Qurban Eid al-Adha, a happy Eid celebration, Fasting Month, Allohuakbar, and Let's Pray.

Based on the phenomenon of these religious symbolic meanings, it can be confirmed that the beliefs are as religious ritual experiences based on the behavior of religious teachings that they embrace. The visualization of children's drawings is a symbolic expression on their religious teachings. There are various religious activities taken as the objects showing the universal symbols of children's drawings. Religion deals with universal values, values of religious beliefs and applying according to the culture in the local area where the children are located.

Symbolic Meaning of Imaginative, Natural Events, Transportation, and Occupation The symbolic meaning is also related to imagination power, and interest in objects or characters of children's stories, as well as cartoon character. The imaginative conditions in these children can produce funny, expressive, unique theme of 'Imaginative' creations. From the children's cognitive experiences when looking at carton movies on the television, as well as through reading and viewing imaginative / imaginative stories in magazines, newspapers, these will provide effectson the presentation of imaginativethemes. There are many symbols of imaginary figures reflected in the names of children favorites, among others areMomo, Mickey Mouse, Winie The Pooh, Angriy Brids, 
Dinosaurs, Hello Kity, Spongebob, Barby, Ipin-Upin, Supermen, Batman, and others. It is confirmed that visual artwork by Jazuli (2008) serves to convey story, to understand ideas and feelings, to decorate life with certain decorations. In these imaginative themes, children want to recount a character according to their imaginary power captured by their cognitive abilities.

The symbolic meaning relates to natural events, transportation, work, the meaning of events in the universe that the children feel and remember as an unforgettable impression. The events can be felt because of its awesomeness, or a terrible, frightening and as a new experience in a child's life. The meaning of "Natural Event" is expressed in the children's drawings, such as Beating the Villain, Cracker Feeding Competition, Landing Helicopter, the Accident, the Flood, the Eruption Mountain, the Coconut Fruit falls. Tsunami, Landslide, and others.

The symbolic meanings of "Transportation" are found in some titles of drawings such as Private Car, My new Bicycle, Riding Train, Riding Delman, Riding Recreation Bus, Sailboat, Cruise ship. The quite dominant types of land transportation means as the source of ideas expressed in some children's drawing are cars, bicycle, trains, Delman combined with the children experiences while riding the means of transportation. In addition, there is also an interest to describe the existing transportation found in the sea.

A person's occupation also becomes a symbolic meaning drawing attention of the children. Based on the children's drawing document, there is a diversity of symbolic meanings expressed in their drawings with the themes of "occupation" such as: Hygiene Officers, Jamu Seller, My Idol, Stewardship, Photo Makers and Mother, Shepherd, Buffalo Shepherd, and Father Plowing in Paddy Field, and Cultivating.

\section{Conclusion}

The diversity of symbolic meanings expressed in the children's drawings relates to the illustration of an idea into the composition of visual elements according to the creative style owned by each child. The diversity of symbolic meanings on the elementary schoolchildren drawings can be seen in many themes, such as: Myself, Playing, Animals, Activity / Hobby, Landscape, Public Places or Objects, Art, Performing Arts, Atmosphere, Place / Environment, Events, Religious, Sports, and Imaginative. It can be found similarity in the various symbols displayed on each drawing, and there are different ones. The symbolic meaning relates to some objects such as people, animals, plants, imaginative objects with so many characteristics of styles or ways in describing them. The diversity of symbolic meanings expressed in children's drawings is a manifestation of life's illustration and the expression on the natural surroundings, human behavior, animals, and cultural products and activities according to the emotional power owned by children. There is a subjectivity of expression according to the children taste to interpret the reality and imaginative into the symbols in the children's drawing artworks.

The diversity of composition of elementary school children's drawing artworksexpressed through the elements line, shape, and color; theseelements are generally functioned to form symbolic meanings of ideas / ideas, charts, shapes of objects, locations, positions, direction, size, motion and others. The symbolic meaning of an object is expressed by presenting various colors, spontaneity, rough, free, and also coloring in a careful, flat, and smooth manner, also having impressions of cool, cold, dim, hot atmosphere and others. 
The symbolic meaning of space impression relates to the shapes of objects, location, size, number of objects, and form / shape of object as encouraging the attention. The impression of space relates to an object in flat or parallel position, following the boundary of plot of land, according to the boundary of road, overlapping and increasingly stacking above the drawing field.

Based on the results of research, it can provide suggestion namely the matters to be followed up on any follow-up researches, namely. (1) A research on symbolic meanings expressed in the elementary school children's drawings in East Java, which is based on the results of illustration of media diversity and art techniques used in the drawing. (2) A research on the perspective of drawing / painting artwork beauty according to the appreciative attitude by elementary school children. (3) It is necessary to conduct follow up by making writing and completion of textbooks as a reference material for art education which is focused on the diversity of themes, objects and symbolic meanings expressed in the elementary school children's drawings.

\section{References}

Iswidayati, S. 2006. Pendekatan Semiotik. Seni Lukis Jepang Periode 80-90an. Kajian Estetika tradisional Jepang wabi sabi. Semarang: UPT UNNES Press.

Jazuli, M. 2008. Paradikma KontekstualPendidikan Seni, Surabaya: Unesa Press.

Kustiawan, 2012. Estetika dan Tipologi Gambar Anak-anak SD. Jurnal SD, tahun 21, Nomor 2, November 2012. Malang: Jurusan KSDP FIP UM.

Maghfiroh, Wahyu, 2012. Studi Tentang Karakteristik Gambar Ekspresi Karya Siswa SDN Karangbesuki 4 Sukun Kota Malang. Malang: Lemlit UM.

Masitoh, dkk. 2007. Strategi Pembelajaran TK. Jakarta: Penerbit Universitas Terbuka.

Pamadhi, Hajar, dkk. 2008. Seni Keterampilan Anak. Jakarta: Penerbit UT.

Rokhmat, Nur. Triyanto. M. Rondhi. 2004. Profil Wanita dalam Karya Seni Reklame Visual. Semarang: Jurnal Imajinasi FBS UNNES.

Sachari, Agus. 2004. Pengantar metodologi Penelitian Budaya Rupa. Jakarta: Penerbit Erlangga.

Salam, Sofyan. 2001. Pendidikan Senirupa di Sekolah Dasar. Makasar. State University of Makasar.

Sumandiyo, Hadi. 2006. Seni dalam Rirual Agama. Yogjakarta: Pustaka.

Sumanto, Made Seken dan Usep Kustiawan. 2011. Kajian Estetika dan Tipologi Gambar Anak Sekolah Dasar di Jawa Timur. Malang: Lemlit UM.

Sumanto, Usep Kustiawan, Sri Sudarmi. 2014. Kajian Tema dan Obyek Gambar Anakanak Sekolah Dasar. Journal of Elementary School of the year 23 May 2014. Malang: Department of KSDP FIP UM.

Sumanto. 2013. Estetika Gambar Anak Sekolah Dasar. Malang: FIP UM.

Syafiiet al. 2002. Materi dan Pembelajaran Kertakes SD. Jakarta: Pusat Penerbitan Universitas Terbuka. 